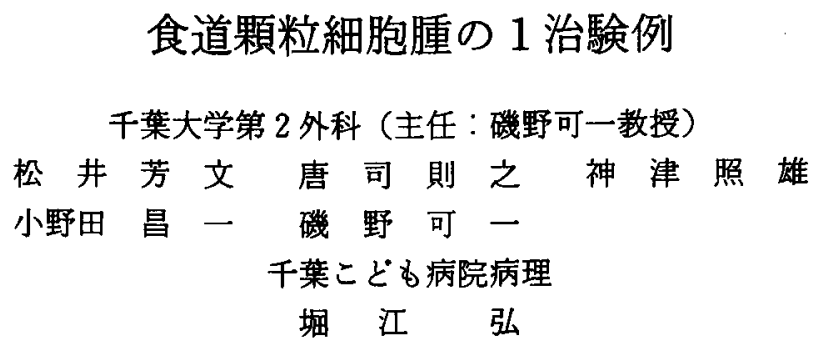

颗粒細胞腫は，1926年 Abrikosoff により報告された腫痬で，特に舌，皮厚に好発する とされており，消化管，特に食道の発生例はまれである，組織発生については，当初筋 肉細胞由来とされていたが，現在では，比較的良性のSchwann 細胞由来であると考えら れている. 本邦では，1987年までに61例の記載がみられるに過ぎない。症例は46歳男性. 内視鏡にて胃漬瘍精查中，下部食道に隆起性病变を指摘され，顆粒細胞腫の診断で下部 食道胃全摘術を施行した。本症は無症状で検診にて偶然発見される頻度が高い，大きさ は，ほとんどが10mm 前後の小さいもので，部位は下部食道に多い，肉眼形態を小隆起 型, Sweet corn 型，大曰䛧型の 3 型に分類すると，大田型が過半数を占め最も多い. 治療は, $10 \mathrm{~mm}$ 前後の小さいものでは経過観察，または Polypectomy が選択されている が, 30mm 以上の大きいものでは手術療法の適応と考えられる.

卖引用語：食道顆粒細胞腫, S-100蛋白染色, Schwann 細胞

\section{緒言}

食道 Granular cell tumor は, 1926年 Abrikossoff により剖検例において，初めて記載された1).今回われ われは，内視鏡生検により診断を得，外科的に切除し た症例を経験したので，文献的考察を加え報告する。

$$
\text { 症例 }
$$

患者：46歳，男性.

主訴：心窝部痛.

既往歴：昭和58年虫垂炎, 昭和61年胃潰瘍。

家族歴：特記すべきことなし．

現病歴：昭和63年 4 月，心骷部痛が出現し近医にて 内視鏡検查の結果, 胃角部に潰瘍が認められた他, 下 部食道の隆起性病变を指摘された。食道癌の疑いで千 莱大学第 2 外科に紹介され, 同年 5 月 18 日, 入院となっ た.

入院時現症：身長 $165 \mathrm{~cm}$, 体重 $50 \mathrm{~kg}$, 栄養状態良好, 費血，黄疾なく，頸部リンバ節は触知しなかった。

入院時検查成績：血液所見，腫痬マーカー，および 胸部 X 線では特に異常は認められなかった。

1989年10月 6 日受付 1990年 4 月 4 日採用
食道およひ胃 X 線所見 (図 1)：食道 $\mathrm{Ei}$ 左後壁に辺 縁整からなる隆起性病変を認める。 また胃角部に Nische が認められた。

内視鏡所見（図 2）：門雪列より $41 \mathrm{~cm} ， 4$ 時の方向 に, 大きさ $5 \mathrm{~mm}$, 高さ約 $2 \mathrm{~mm}$ で黄白色の山田型の隆 起性病变を認め, 粘膜下腫幏と診断された. 頂上部に 小さな陷凹を有し発赤を伴っていた，病変頂上部より 2 力所生検を行なった。

超音波内視鏡所見（図 3)：食道粘膜下㬝に限局する 大きさ $12 \mathrm{~mm}$ の腫瘤を認め, 沼緑は整, 境界は明瞭, 内部ェューはlowであった。

生検所見：HE染色では，いわゆる pseudoepitheliomatous hyperplasia を伴ら扁平上皮下に，明るい 好酸性の豊富な胞体を有する紡形稩胞が増殖してい る。をた腫場内に基底細胞が島状に孤立している（図 4a).

PAS 染色陽性の微細顆粒が胞体内に多数認められ た（図 4b)，また，PAP 法によるS-100蛋白染色で虫， 細胞質が赤染され，陽性であった（図 4c).

以上の検查結果より, 顆粒細胞腫と診断され, 昭和 63年 6 月 1 日, 左第 7 助間開胸開腹にて下部食道胃全 


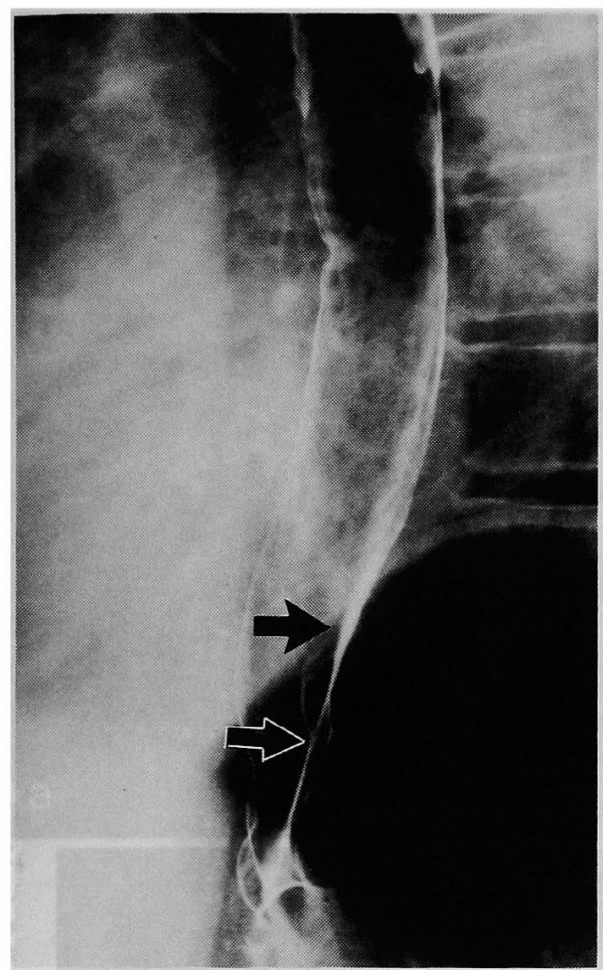

左

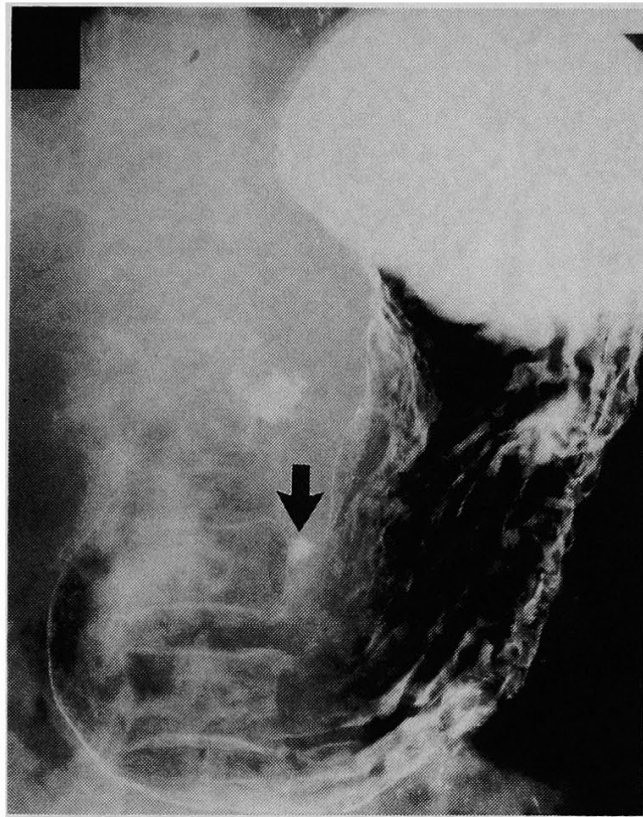

右

图 1 左：食道二重造影像： $\mathrm{Ei}$ 後壁に隆起性病变を認める。 右：胃二重造影像：胃角部に Nische を認める.

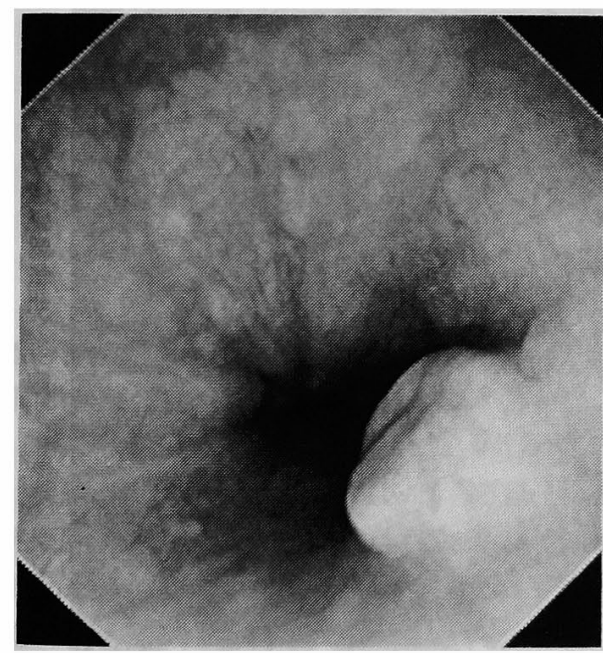

图2 食道内視鏡像：4 時の方向に山田III型の隆起性 病変を認める。

摘術を施行した。

手術所見：胸水，腹水なく，胃周囲のリンパ節は资

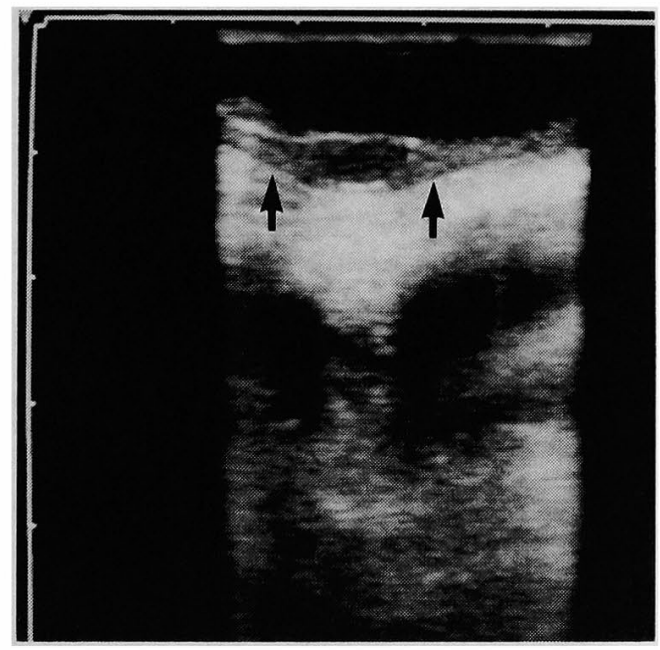

図 3 超音波内視鏡像：粘膜下層に限局する腫瘤を認 める。

症性に腫大していた。

切除標本所見：胃角部に潰瘍が認められる他, 食道 


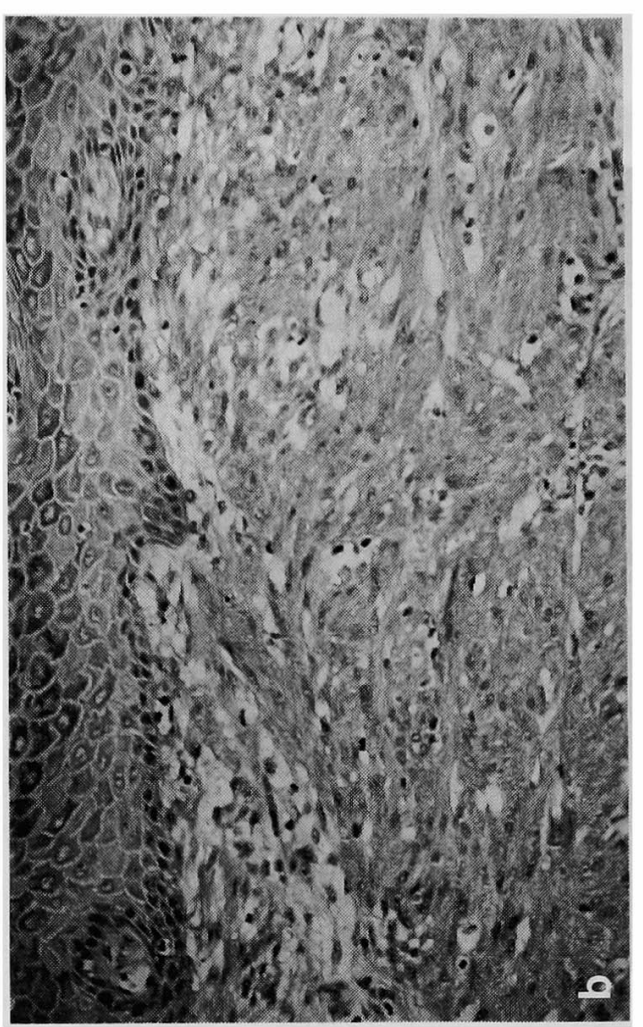

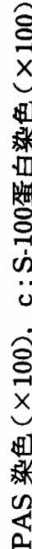
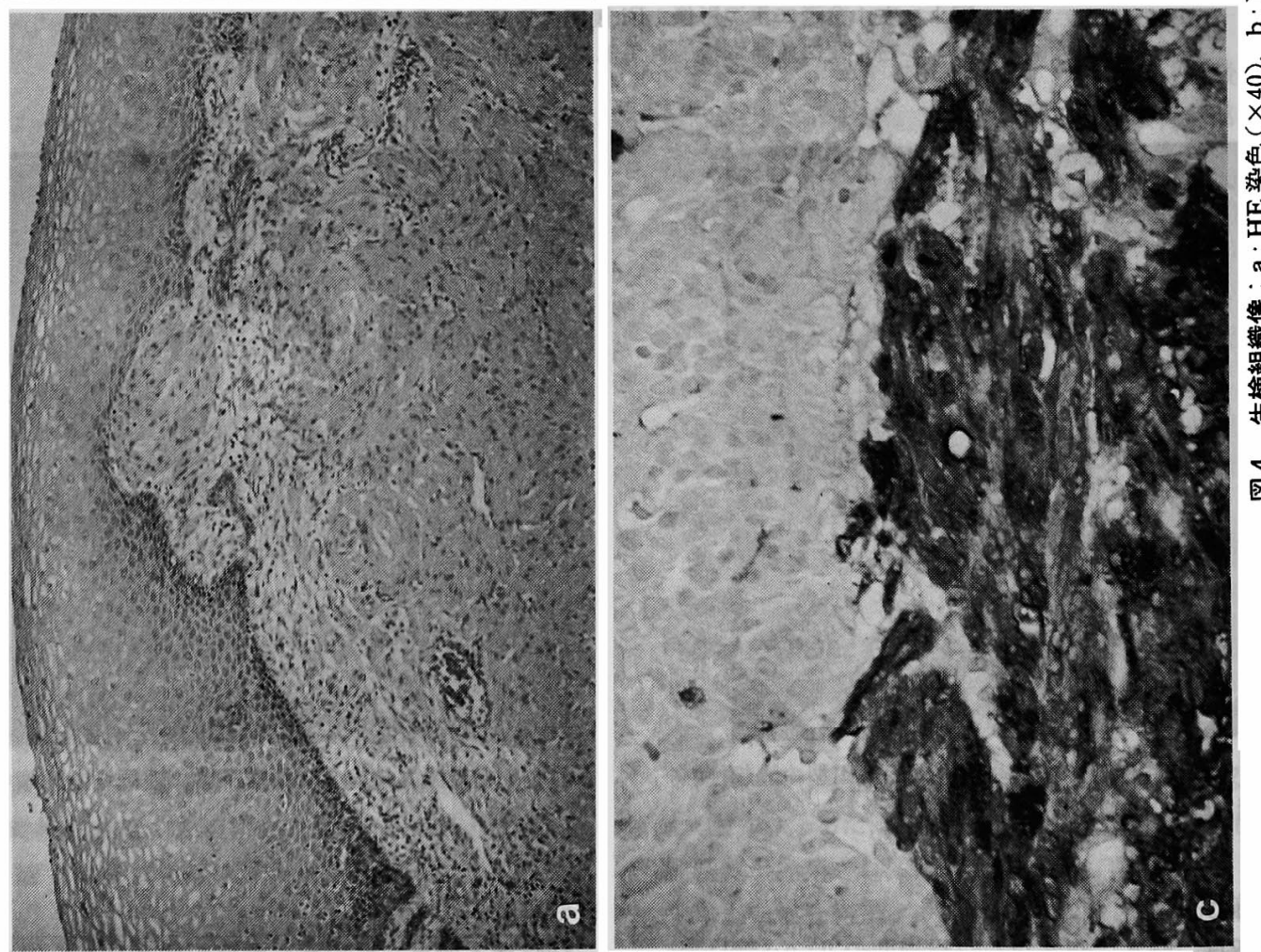

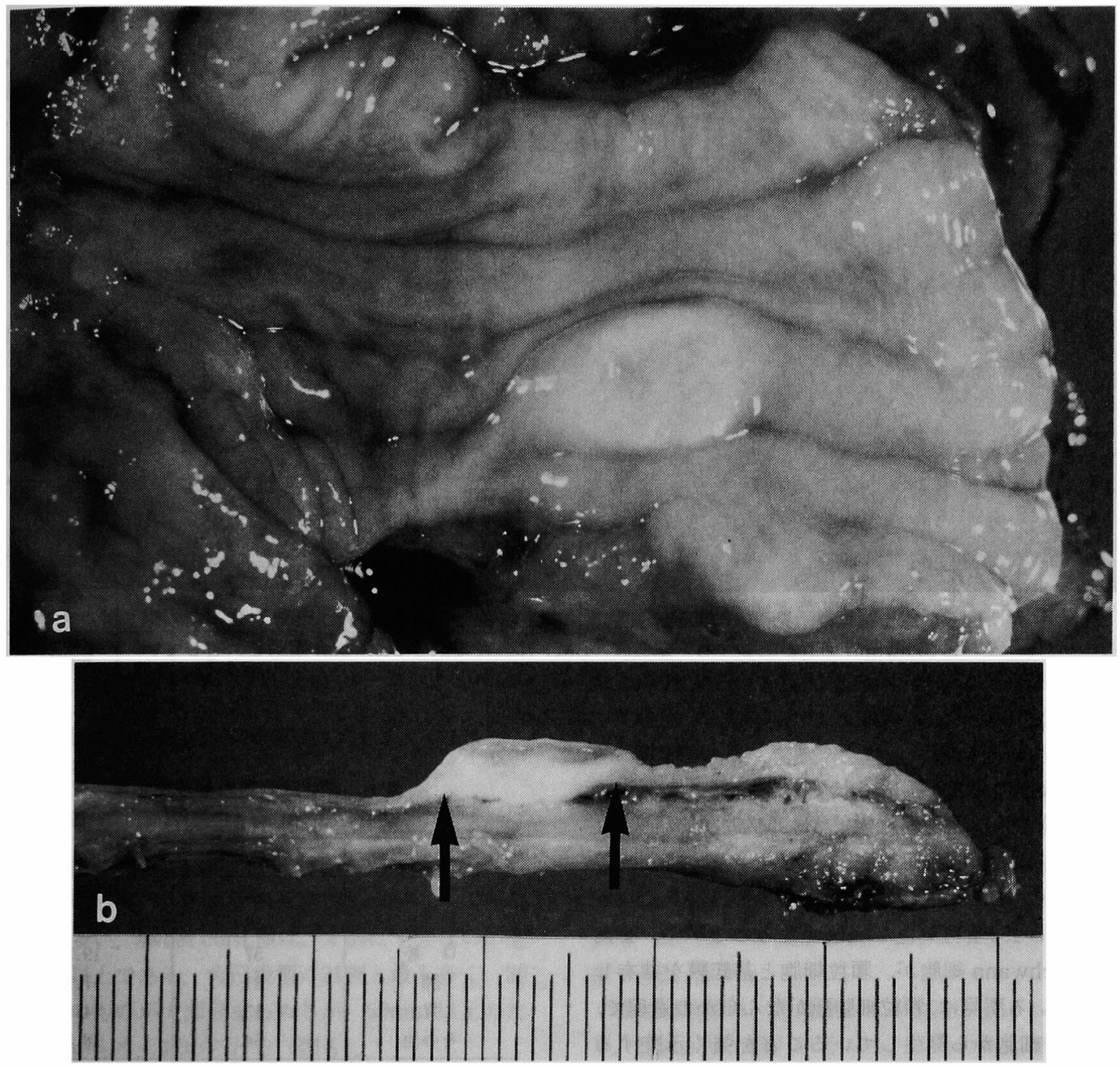

図 5 切除標本：a；肉眼所見, $b$; 割面所見

胃接合部より口側 $15 \mathrm{~cm}$ に大きさ $12 \times 7 \times 3 \mathrm{~mm}$ の白色 で頂部に陥凹を伴った隆起性病変が認められた（図 5 a)。ホルマリン固定標本の割面では固有筇層は保た れ，病変は粘膜下層に限局している（図 5b).

光影所見：生検とほぼ同様の所見であり, pseudoepitheliomatous hyperplasia も同様に認められた.

電䫓所見：細胞質に多くの electron dense granule を含んだ細胞が多数散在し, 顆粒の乏しいSchwann 細胞が隣接している. Schwann 細胞の細胞膜は折り返 り，軸索間膜を形成している，また基底膜 (BM) は顆 粒細胞と schwann 細胞を共有している（図 6 ). 術後 経過良好で, 昭和63年 6 月 26 日退院, 再発の兆候なく,

\section{現在経過観察中である.}

考察

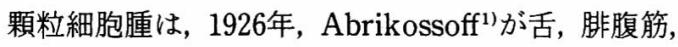
上口唇の Myoblastenmyoma として報告したもので, 皮膚, 乳腺, 食道, 胃, などにも発生するとされてい る.

食道顆粒細胞腫は比較的まれな疾患で，欧米では Coutinhoによる報告2)では1985年までに119例の記載 が認められる。本邦では1975年の崔ら゙による症例が 第 1 例であり，1987年までに61例の報告がみられるに 過ぎない。

組織発生として, 筋源説 ${ }^{1)}$, 組織球説 ${ }^{4)}$, 肉芽腫説 ${ }^{5)}$, 


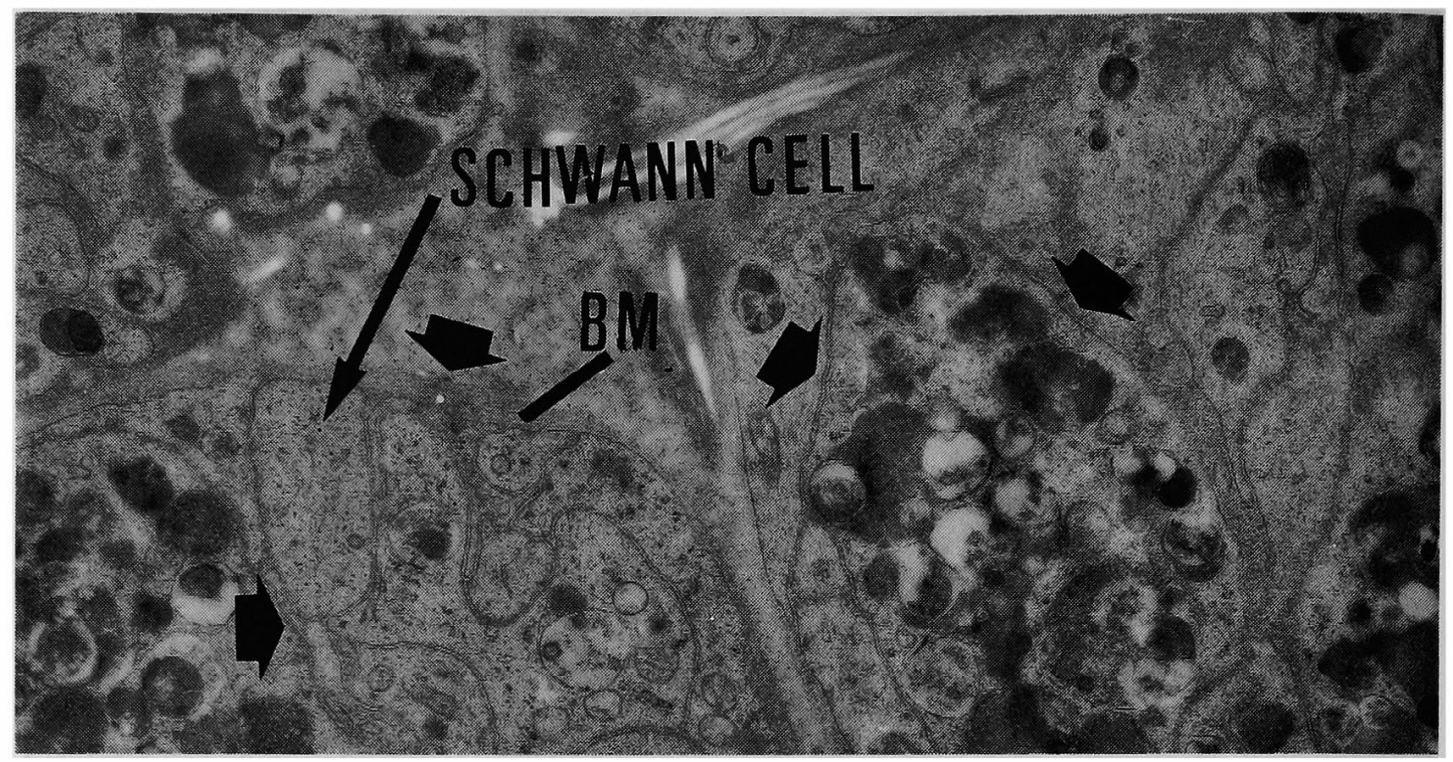

图 6 電子顕微鏡所見 $(\times 8,000)$ : 細胞質に多くの electron dense granuleを含んだ細胞 と Schwann 細胞が隣接する，基底膜（BM）は顆粒細胞と Schwann 細胞を共有してい る.

神経説6)などの諸説が提唱されてきた。しかし，現在で は組織化学的7), 免疫組織学的8)扣よび電顕的研究9)な どにより，Schwann 細胞由来と考兄られている．自験 例のごとく, PAP 法 (酵素抗体法) で神経特異蛋白と いわれるS-100蛋白染色が陽性であること10111，また 電顕上 Schwann 細胞が，顆粒細胞と基底膜を共有し 隣接している所見は, 顆粒細胞腫がなんらかの過程で, Schwann 細胞から発生していることを強く示唆する ものである.顆粒細胞腫は一般に良性とされているが, リンパ節転移，遠隔転移など臨床的悪性所見を示する のが $2 \sim 3.4 \%$ 存在するとの報告もみられる2121). 本邦 例では, 臨床的悪性例はみられないが, 組織学的に核 の異型性を示す例が 3 例 (4.9\%) 報告されてい る13) 15). しかし転移, 再発例の記載は認められない.

（1）顆粒細胞腫の部位別頻度

皮膚が $30.5 \%$ と最も多く, 次いで食道, 口腔が各々 19.5\%となっている（表 1 ).

（2）食道顆粒細胞腫の性・年跉分布

年柃分布は， 40 歳台に最も多く $(43.5 \%)$, 性別頻度 では, 約 4：1 と男性に多い.

（3）部位と大きさ

部位別では頸部食道は 2 例と少ないが，大きさは50 $\mathrm{mm}$ 以上と比較的大きい，胸部および腹部食道では20
表 1 顆粒細胞腫の部位別頻度

\begin{tabular}{c|c|c}
\multicolumn{3}{|c}{ 一本邦報告例291例 $(1933 \sim 1987)-$} \\
\hline 部 位 & 症例数 & 頻度\% \\
\hline 皮 膚 & 89 & 20.5 \\
食 道 & 57 & 19.5 \\
口 腔 & 57 & 19.5 \\
肺 & 21 & 7.2 \\
胃 & 13 & 4.5 \\
その他 & 54 & 18.8 \\
\hline 計 & 291 & 100 \\
\hline
\end{tabular}

$\mathrm{mm}$ 以下の小さいものが多い。 また，特に下部食道で は25例と最も多く，好発部位となっている(図7).

\section{（4）症状と無症状例の発見動機}

曣下困難，心窩部痛が各々 $15.7 \%$ どと有症状例は 少なく，無症状にて発見されるものが32例，62.7\%と 過半数を占めている. 無症状例の発見動機では, 検診 が71.9\%と偶然に発見されることが最も多い.

（5）肉眼形龍と大きさ

本邦報告例における肉眼形態の表現では, 山田の分 類を初め,「sweet corn 様」「大田歯様」などが多く用 いられている，著者は本邦報告例36例について，肉眼 形態を小隆起型, sweet corn 型, 大臼歯型の 3 型に分 


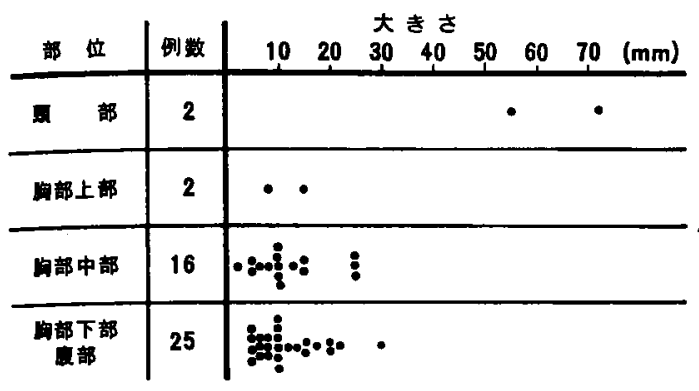

図7食道頺粒細胞㰌の部位と大きき：一本邦報告例 45例一

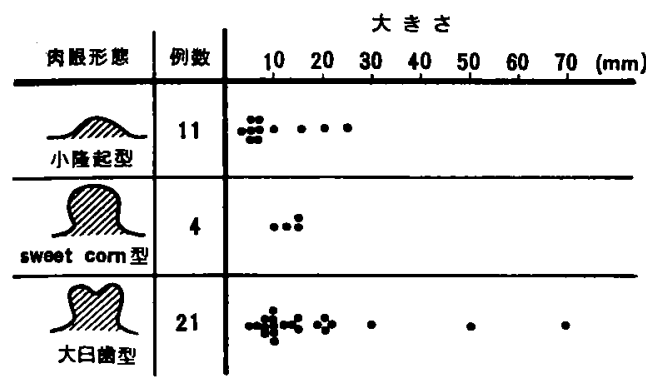

图 8 食道顆粒細胞腫の肉眼形態と大きさ一本邦報告 例36例一

類し，畽場の発育形態について検討した，その結果， 小隆起型は11例で，そのうち 8 例が $10 \mathrm{~mm}$ 以下と小さ いものが多い. sweet corn 型は，4例にすぎないが全 て10 mm 以上である. 大日型は21例と最も多く，20 $\mathrm{mm}$ 以下のものが大部分を占めるが，50 $\mathrm{mm}$ 以上の比 较的大きいるのる認められる（图 8).

著者の肉眼形態分類において，小さいものは小隆起 型が多く，一方大きいむのは大臼歯型が多い傾向にあ ることより，小隆起型であるるのが径の増大に従い， 頂上部に宿凹を伴ら大日歯型へ発育していくと推定さ れた.

内視鏡の普及と, boring biopsy などの技術的な進歩 に伴い，生愉のみで確定診断がつくことが多い，しか し手街により初めて診断されたものも46例中 9 例, 19.6\%にみられている. 平滑筋腫や polyp などとの鑑 別診断が重要であるが，顆粒細胞睰は，大きさは小さ く，硬く，大歯型を示寸すのが多い。

（6）大きさからみた治原法

畽場の大きさ別治療法に招いて，10 $\mathrm{mm}$ 以下では polypectomy が半数を占め, 次いで経過観察となって いる. $30 \mathrm{~mm}$ 以下では， polypectomy と核出術が各々
表 2 食道頼粒細胞朠の大きさからみた治療法

一本邦報告例 42 例一

\begin{tabular}{|c|c|c|c|c|c|}
\hline 大きさ & 例数 & $\begin{array}{l}\text { ボリ } \\
\text { ペクト }\end{array}$ & 核出術 & 妡除術 & 経過観察 \\
\hline $\begin{array}{r}\leqq 10 \\
(\mathrm{~mm})\end{array}$ & 24 & $(50.0)$ & $\begin{array}{c}3 \\
(12.5)\end{array}$ & 0 & $\begin{array}{c}9 \\
(37.5)\end{array}$ \\
\hline$\leqq 30$ & 16 & $\begin{array}{c}6 \\
(37.5)\end{array}$ & $\begin{array}{c}6 \\
(37.5)\end{array}$ & $\begin{array}{c}2 \\
(12.5)\end{array}$ & $\begin{array}{c}2 \\
(12.5)\end{array}$ \\
\hline $30<$ & 2 & 0 & $\begin{array}{c}1 \\
(50.0)\end{array}$ & $\begin{array}{c}1 \\
(50.0)\end{array}$ & 0 \\
\hline
\end{tabular}

$37.5 \%$ と同じ頻度となっている， $30 \mathrm{~mm}$ より大きいる のでは，いずれす手術例であった（表 2).

顆粒細胞腫は，一般的に良性疾患とされているが， 本邦報告例では， 3 例の悪性例 ${ }^{13) \sim 15)}$ がみられる。 しか し，いずれも手術にて治瘦しており再発は認められて いない.一方, Obiditsch-Mayer ら ${ }^{161}$ は気管および頸部 リンパ節に転移後死亡した 1 例を報告している，治療 法の選択に関し，川上ら ${ }^{17}$ は長径 $22 \mathrm{~mm}$ の顆粒細胞腫 に polypectomy を施行したが, 術後穿孔し保存的療法 にて治瘜した経駼より, polypectomy も慎重に行らこ とが重要であると強調している. Peterson ら ${ }^{18)}$ は, 顆 粒細胞腫は粘膜下由来であるため再発の可能性がある ので,内視鏡的切除は望ましくないと述べている.Sandler ら ${ }^{19}$ は明らかに有茥性のすののみ内視鏡的切除が 勧められると述へ，その適応を爰格にしている，自験 例は，難治性の胃潰瘍を合併しているため手術療法を 第一選択とした。

顆粒細胞腫は，悪性度が低く発育が遅いことなどよ り，悪性が強く疑われるもの，または有症状例にのみ 治療を行えば十分と考兄られる。治療法としては，大 きさが大く技術的に polypectomy が困難な症例に は，外科的切除の適応があると考える。，一方，無症状 で，良性である場合には，内視鏡による定期的経過観 察で十分と思われる。

結語

46歳男性に発生した食道顆粒細胞腫の 1 切除例を経 験し，本邦報告61例について若干の文献的考察を加え 報告した。

\section{文献}

1) Abrikossoff A: Über Myoma ausgehend von der quergestreiften willkürlichen Muskulatur. Virchows Arch Path Anat 260 : 215-233, 1926

2) S de S Coutinho, Soga J, Yoshikawa T, et al: Granular cell tumors of esophagus, a report of 
two cases and review of the literature. Am J Gastroenterology 80 : 758-762, 1985

3）崔 相羽, 北川睦夫，佐田 博他：食道に発生した 顆粒細胞腫の 1 例，日消病会誌 $72: 473,1975$

4) Leroux R, Delarue J : Sur trois cas de tumeurs à cellules granuleuses de la cavité buccale. Bull Assoc Franc Etude Cancer 28 : 427-447, 1939

5) Gullino P : Sui cosidetti 'tumori di mioblati' interpretati come granulomi die probabile origin parasitaria. Tumori $20: 102,1946$

6) Fust J, Custer RP: On neurogenesis of socalled cell myoblastoma. Am J Clin Path 19 : 522-535, 1949

7) Bangle R Jr: A morphological and histochemical study of granular cell myoblastoma. Cancer 5 : 950-965, 1952

8) Penneys NS, Adachi K, Ziegelsweissman J, et al: Granular cell tomors of the skin contain myelin basic protein. Arch Pathol Lsb Med 107 : 302-303, 1983

9) Sobel HJ, Marquet E, Schwarz R : Is schwannoma related to granular cell myoblastoma? Arch Path 95 : 396-401, 1973

10) 中島 孝：神経組䄉特異蛋白（S-100ならび NSE 蛋白）による睡瘍の免疫組織学的検索とその診断 への応用, 病理と臨 $1: 115-124,1983$

11）向井万起男：Granular Cell Tumor の組織発生,
病理と臨 1:125-132, 1983

12) Vuyk HD, Snow GB, Tiwari RM, et al : Granular cell tumor of the proximal esophagus. Cancer $55: 445-449,1985$

13）甲利 幸, 谷口健三, 古河 洋：食道原発の Granular cell myoblastoma の 1 治験例, 日消外会誌 $15: 355,1982$

14）佐々木哲二, 青木春夫，笠原正雄：組織学的に悪性 所見を呈した食道 Granular cell tumor $の 1$ 例, 臨外 36:1645-1649, 1981

15）大森高明：食道悪性 GCT $の 1$ 症例, 日病理会誌 $75: 357,1986$

16) Obiditsch-Mayer 1, Salzer-kuntschik $M$ : Malignes, "gekorntzelliges Neurom", sogenanntes "Myoblastenmyom" des oesophagus. Beitr Pathol Anat 125 : 357-373, 1961

17）川上抱負, 藤田 力, 村瀬永策他：内視鏡的ポリヘ クトミーをした食道 granular cell tumor の 1 例, 消内視鏡の進歩 $24: 215-218,1984$

18) Peterson PA, Edward HS, Bernartz PE: Benign granular cell myoblastoma of the bronchi. Report of two cases. Thorac Cardiovasc Surg 34 : 95-104, 1957

19) Sandler RS, Wood DR, Bozymski EM : Endoscopical removal of a granular cell tumor of the esophagus. Gastroenterol Endosc 27 : 70-72, 1981

\title{
A CASE REPORT OF GRANULAR CELL TUMOR OF THE ESOPFAGUS
}

\author{
Yoshifumi MATSUI, Noriyuki TOHNOSU, Teruo KOUZU, Shoichi ONODA, \\ Kaichi ISONO and Hiroshi HORIE* \\ Second Department of Surgery, School of Medicine, Chiba University \\ *Central Laboratory Division, Chiba Children Hospital
}

Granular cell tumor (GCT), first reported in 1926 by Abrikossoff, is frequently found in the tongue and skin but rarely in the gastrointestinal tract, especially in the esophagus. Although GCT had been thought to originate from striated muscle cells, recently it is considered that GCT is derived from Schwann cells which are relatively benign.

Sixty-one cases of GCT of the esophagus have been reported in Japan up to 1987 in the review of the literature. In 46-year-old male complaining of occasional epigastralgia, esophagogram and endoscopy demonstrated an elevated lesion in the lower esophagus as well as gastric ulcer. Lower esophageal and total gastric resection was performed on June 1, 1988. Most of GCTs are occasionally detected in a mass-screening and most patients are asymptomatic. GCTs are commonly as small as around $10 \mathrm{~mm}$ in diamater, and tend to be located in the lower esophagus.

When GCTs were classified into a slightly elevated, sweet corn, and ture molar shapes, the true molar shape was most commonly seen. In the treatment of GCTs, endoscopic follow-up or polypectomy is recommended for those as small as about $10 \mathrm{~mm}$ in diameter, but for larger GCTs over $30 \mathrm{~mm}$ surgical treatment is indicatable. 